Syntax Literate : Jurnal Ilmiah Indonesia p-ISSN: 2541-0849 e-ISSN: 2548-1398

Vol. 5, No. 4 April 2020

\title{
PENGARUH KEPEMIMPINAN LURAH TERHADAP EFEKTIVITAS KINERJA PEGAWAI DI KELURAHAN CIAKAR KECAMATAN CIBEUREUM KOTA TASIKMALAYA
}

\section{Endri Herlambang}

Sekolah Tinggi Ilmu Sosial dan Ilmu Politik (STISIP) Tasikmalaya

Email: endriherlambang.88@gmail.com

\section{Abstract}

One concept that influences employee performance is the influence of leadership. Likewise, in the context of government activities, it is inseparable from the influence of its leadership in managing the organization it leads to be more productive and its employees have good performance. This research aims to: 1) test the hypothesis of the influence of the leadership of the Lurah on the effectiveness of employee performance in Ciakar Village, Cibeureum District, Tasikmalaya City; and 2) to determine the performance of village staff and to improve the performance of village staff as part of government officials who carry out the task of serving public needs. The research method used in this study is a quantitative research method. Quantitative research is a form of scientific research that examines a problem from a phenomenon, and looks at the possible links or relationships between variables in a given problem. Hypothesis testing results show a correlation matrix between two variables. Correlation between Lurah leadership and employee performance was obtained 0.469, this means that $46.9 \%$ of the data are both very positively related. Furthermore the results of the correlation level of the data have a fairly strong level of relationship, which is between 0.40 - 0.599. The results of the study concluded that the Lurah's leadership had a positive and significant effect on the effectiveness of employee performance in Ciakar Village, Cibeureum District, Tasikmalaya City. That is; the higher the influence of leadership, the employee's performance will increase. Leadership includes; power, competence, credibility, courage, will and enthusiasm.

Keywords: leadership, headman, effectiveness, employee performance.

\footnotetext{
Abstrak

Salah satu konsep yang mempengaruhi kinerja pegawai, yakni pengaruh dari kepemimpinan. Begitu pula dalam konteks aktivitas pemerintahan tidak terlepas dari pengaruh pimpinannya dalam mengelola organisasi yang dipimpinnya untuk menjadi lebih produktif dan para pegawainya memiliki kinerja yang baik. Penelitian ini bertujuan untuk: 1) menguji hipotesis besarnya pengaruh kepemimpinan Lurah terhadap efektivitas kinerja pegawai di Kelurahan Ciakar Kecamatan Cibeureum Kota Tasikmalaya; dan 2) untuk mengetahui kinerja pegawai kelurahan dan untuk perbaikan kinerja pegawai kelurahan sebagai bagian dari aparat pemerintah yang mengemban tugas untuk melayani kebutuhan publik. Metode penelitian yang digunakan dalam penelitian ini adalah metode penelitian
} 
kuantitatif. Penelitian kuantitatif merupakan satu bentuk penelitian ilmiah yang mengkaji satu permasalahan dari suatu fenomena, serta melihat kemungkinan kaitan atau hubungan-hubungannya antar variabel dalam permasalahan yang ditetapkan. Hasil pengujian hipotesis menunjukkan matriks korelasi antara dua variabel. Korelasi antara kepemimpinan Lurah terhadap kinerja pegawai diperoleh angka 0.469 , hal ini berarti $46,9 \%$ data keduanya sangat berhubungan secara positif. Lebih jauh hasil tingkat korelasi dari data tersebut mempunyai tingkat hubungan yang cukup kuat, yakni berada diantara 0.40 - 0.599. Hasil penelitian dapat disimpulkan kepemimpinan Lurah berpoengaruh positif dan signifikan terhadap efektivitas kinerja pegawai di Kelurahan Ciakar Kecamatan Cibeureum Kota Tasikmalaya. Artinya; semakin tinggi pengaruh kepemimpinan, maka kinerja pegawai akan meningkat. Kepemimpinan meliputi; kekuasaan, kompetensi, kredibilitas, keberanian, kemauan dan semangat.

Kata kunci: kepemimpinan, Lurah, efektivitas, kinerja pegawai.

\section{Pendahuluan}

Di era informasi dan komunikasi seperti sekarang ini, salah satu tantangan terbesar lembaga-lembaga pemerintahan adalah bagaimana cara mengoptimalkan semua sumber daya yang dimiliki, salah satunya Sumber Daya Manusia (SDM). Optimalisasi semua sumber daya yang dimiliki oleh lembaga pemerintahan merupakan suatu keharusan yang tidak bisa ditawar. Hal tersebut dimaksudkan agar lembaga tersebut mempunyai daya saing dan mempunyai performansi yang baik.

Salah satu lembaga pemerintahan yang erat kaitannya dengan beragam kegiatan pembangunan bagi masyarakat, adalah kelurahan. Kelurahan sebagai bagian dari sistem pemerintahan daerah mempunyai peranan penting dalam sendi pemerintahan daerah, baik dari segi administratif maupun fungsi bagi masyarakat, dan kelurahan dipimpin oleh seorang Kepala Kelurahan atau sering disebut dengan Lurah. Menurut Peraturan Pemerintah No. 73 tahun 2005, menyatakakan bahwa "Kelurahan adalah wilayah kerja lurah sebagai perangkat Daerah Kabupaten/Kota dalam wilayah kerja Kecamatan.” Oleh karena itu, Lurah mempunyai peranan yang sangat vital dalam mengelola kelurahan dan mempunyai tugas pokok menyelenggarakan urusan pemerintahan, pembangunan dan kemasyarakatan.

Performasi sebuah lembaga pemerintahan tidak lepas dari peran pemimpin dan kinerja pegawainya. Selama ini lembaga pemerintahan baik di tingkat pusat maupun di tingkat daerah belum sepenuhnya memberdayakan potensi yang ada dan belum sepenuhnya berorientasi pada pencapaian kinerja. Dengan melakukan optimalisasi semua sumber daya yang dimiliki sebuah lembaga pemerintahan tersebut, maka diharapkan berbagai problematika yang dihadapi oleh lembaga tersebut dapat dipecahkan atau dikurangi.

Namun dalam kenyataannya terdapat faktor utama yang menyebabkan rendahnya kemampuan lembaga pemerintahan dalam memberdayakan sumber daya yang dimilikinya adalah lemahnya kepemimpinan lembaga pemerintahan tersebut. 
Suatu organisasi maupun lembaga pemerintahan memerlukan dukungan para anggota berupa performansi kerja guna mencapai tujuan yang ditetapkan.

Kemampuan mencerminkan kesanggupan seseorang untuk melaksanakan tugas sedangkan motivasi mencerminkan bagaimana seseorang dengan penuh semangat menerapkan kemampuannya. Seseorang yang mempunyai kemampuan dan motivasi tertentu, apabila dipadukan maka hasil kerjanya akan nampak pada performansi kerja dalam bentuk efektivitas kerja.

Performansi kerja biasanya identik dengan hasil kerja. Sumber daya organisasi, manusia memiliki potensi kerja yang berpengaruh pula pada efektivitas organisasi. Karena itu performansi kerja setiap individu dan kelompok akan menentukkan peringkat keefektifan organisasi. Performansi kerja yang sesuai dengan ketentuan organisasi akan mempercepat tercapainya tujuan organisasi.

Salah satu bentuk dari etos kerja seorang pegawai dapat dilihat dari tingkat kedisplinan selama bekerja. Hal tersebut dapat dilakukan dengan cara penilaian. Menurut (Heridiansyah, 2014) menyatakan, bahwa "Penilaian prestasi adalah membandingkan antara prestasi aktual bawahan dengan standar yang diharapkan." Artinya jika terdapat pegawai yang belum sesuai dengan standar kerja yang diberlakukan, maka kemungkinan performansi kerjanya kurang baik.

Di sisi lain, khususnya di instansi pemerintahan masih jauh dari kinerja pegawai yang prima. Hal tersebut sejalan dengan hasil laporan Ombudsman (Indonesia, 2015) tentang jumlah pengaduan masyarakat mengenai lembaga publik pada gambar berikut:

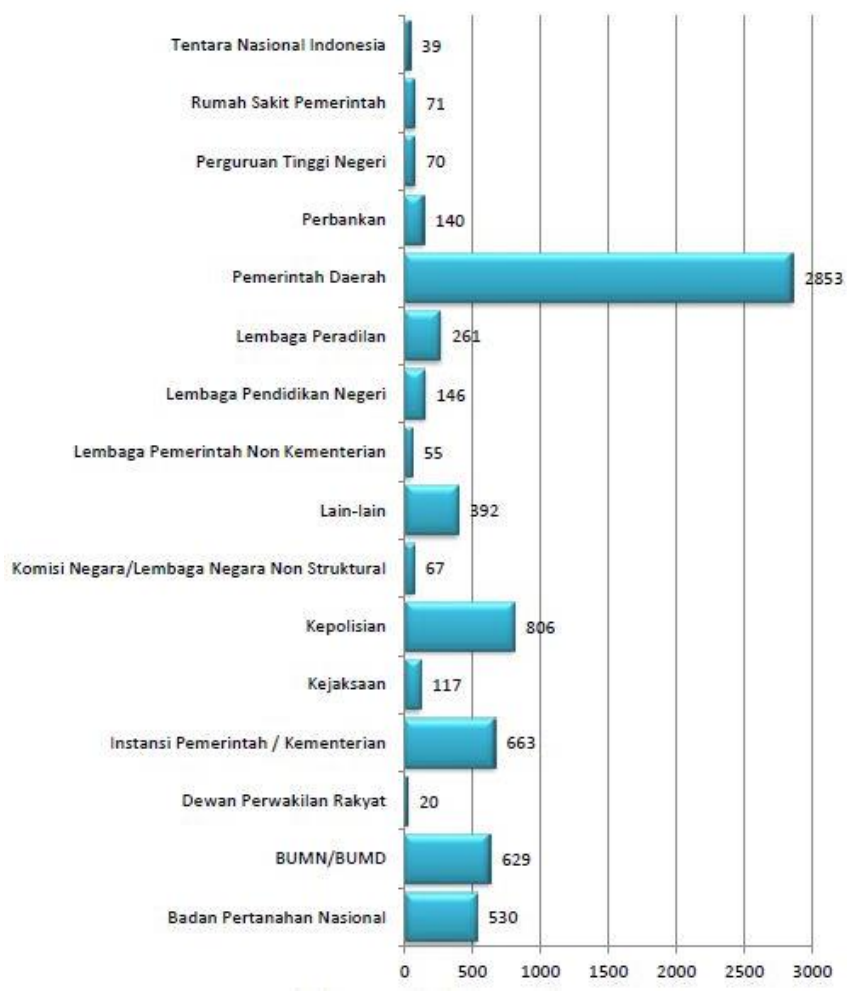

Gambar 1 Jumlah Laporan Masyarakat

Sumber: simpel.ombudsman.go.id, (2015:1) 
Berdasarkan gambar tersebut, dari 6859 (enam ribu delapan ratus lima puluh sembilan) laporan atau pengaduan masyarakat Tahun 2015, sebanyak 41,59\% atau 2853 (dua ribu delapan ratus lima puluh tiga) laporan mengeluhkan penyelenggaraan pemerintahan di instansi pemerintah daerah. Sehingga dapat dikatakan, bahwa terdapat masalah di dalam instansi sebuah pemerintah daerah dalam bidang sumber daya manusia yang menjadi pelaku pemberi kebijakan bagi kebutuhan masyarakat secara administratif.

Selain itu jika dikerucutkan pada sebuah lembaga atau instansi pemerintah, terdapat kurang baiknya kinerja yang diperlihatkan. Hal tersebut dapat dilihat pada tabel, berikut ini:

Tabel 1

Rekapitulasi Kehadiran Pegawai OPD Kelurahan Ciakar Tahun 2016

\begin{tabular}{llcl}
\hline No. & \multicolumn{1}{c}{ Jabatan } & $\begin{array}{c}\text { Presentase Kehadiran } \\
(\boldsymbol{\%})\end{array}$ & Ket. \\
\hline 1. & Lurah & 95 \\
\hline 2. & Sekretaris Lurah & 95 \\
\hline 3. & Kasie Pemerintahan dan Trantib & 100 \\
\hline 4. & Kasie Kesra & 100 \\
\hline 5. & Fungsional Umum & 90 \\
\hline 6. & Fungsional Umum & 90 \\
\hline 7. & Fungsional Umum & 95 \\
\hline 8. & Fungsional Umum & 100 \\
\hline 9. & Fungsional Umum & 95 \\
\hline 10. & TKK & 100 \\
\hline 11. & Sukwan & 100 \\
\hline
\end{tabular}

Sumber: Data Kelurahan Ciakar, Januari 2016.

Jika dilihat dari hasil tabel tersebut, nampak masih ada presentase kehadiran pegawai yang masih belum 100\%. Inilah salah satu kurangnya kinerja pegawai berkaitan dengan motivasi kinerja dan kedisiplinan kerja. Dalam hal ini dapat diyakini kepemimpinan lembaga pemerintah daerah diyakini belum mampu memberdayakan sumber daya manusia yang dimilikinya untuk berkinerja secara efektif dengan membangun komitmen mereka terhadap nilai-nilai baru, mengembangkan keterampilan dan kepercayaan mereka, serta menciptakan iklim yang kondusif bagi berkembangnya inovasi dan kreatifitas. Dalam pengelolaan atau manajemen dalam sebuah lembaga pemerintahan, biasanya menggunakan pendekatan sistem sosial. Dimana menurut (Hasibuan, 2009) menyatakan, bahwa:

"Sistem adalah suatu proses yang terdiri dari berbagai unsur atau komponen yang satu sama lain berkaitan secara struktural dan fungsional, saling menunjang dan mengisi, sesuai dengan peran dan kedudukan masing-masing, namun keseluruhannya secara mutlak di dukung oleh setiap komponen, betapapun kecil nilainya". 
Hal tersebut menunjukkan kinerja pegawai menjadi salah satu dimensi untuk menunjukan performansi sebuah lembaga atau organisasi. Karena menurut (Mangkunegara \& Prabu, 2005) menyatakan, bahwa "Kinerja adalah hasil kerja baik secara kualitas maupun kuantitas yang dicapai oleh seseorang dalam melaksanakan tugas sesuai tanggung jawab yang diberikan." Sejalan dengan hal tersebut, maka penulis membuat penelitian ini dengan judul "Pengaruh Kepemimpinan Lurah Terhadap Efektivitas Kinerja Pegawai di Kelurahan Ciakar Kecamatan Cibeureum Kota Tasikmalaya."

\section{Metode Penelitian}

Metode penelitian yang digunakan dalam penelitian ini adalah metode penelitian kuantitatif. Menurut (Indrawan \& Yaniawati, 2016) menyatakan, bahwa "Penelitian kuantitatif adalah satu bentuk penelitian ilmiah yang mengkaji satu permasalahan dari suatu fenomena, serta melihat kemungkinan kaitan atau hubungan-hubungannya antar variabel dalam permasalahan yang ditetapkan."

Adapun hubungan yang dimaksud dapat hubungan kasualitas maupun fungsional. Hubungan kausalitas merupakan hubungan antar variabel dimana perubahan satu variabel menyebabkan perubahan variabel lainnya tanpa adanya kemungkinan akibat kebalikannya. Sedangkan hubungan fungsional merupakan kedua variabel atau lebih karena sifat fungsinya, yang perubahan satu variabel menyebabkan variabel lain berubah dan demikian pula sebaliknya. Selain itu dalam penelitian ini menggunakan pendekatan verifikatif yaitu metode yang dilakukan untuk menguji hipotesis dengan menggunakan perhitungan dari statistik dengan Software SPSS (Statistical product and Service Solutions) Ver.17.0 For Windows.

Alat dan teknik pengumpulan data yang penulis gunakan dalam penelitian ini adalah sebagai berikut;

1) Studi kepustakaan, yaitu teknik pengumpulan data yang didapat dari mempelajari buku-buku dan bahan kepustakaan lainya yang ada hubunganya dengan masalah yang diteliti.

2) Studi lapangan, yaitu teknik pengumpulan data dengan cara mengumpulkan data yang diperoleh secara langsung di lokasi penelitian, yaitu dengan cara sebagai berikut;

a. Observasi, yaitu teknik pengumpulan data dengan cara mengadakan pengamatan dan pencatatan langsung ke obyek penelitian.

b. Wawancara, yaitu teknik pengumpulan data dengan cara melakukan tanya jawab langsung dengan responden.

c. Angket, yaitu teknik pengumpulan data dengan cara memberikan serangkaian pertanyaan yang disusun secara sistematis pada responden, dengan cara menyebarkan daftar pertanyaan yang secara logis berhubungan dengan masalah penelitian dan bersifat pertanyaan tertutup/berstruktur dimana setiap pertanyaan sudah tersedia 4 alternatif jawaban, sehingga responden tinggal memilih salah satu alternatif jawaban yang dianggap sesuai dengan 
kenyataan. Skala yang digunakan dalam angket tersebut menggunakan Skala Likert.

d. Studi dokumentasi, yakni penelusuran dan perolehan data yang diperlukan melalui data yang telah tersedia.

Guna menjawab permasalahan dan mencapai tujuan penelitian serta manfaat penelitian ini, pemilihan sampel dilakukan dengan cara dispropotionate stratified random sampling. Menurut (Riduwan, 2011) menyatakan bahwa "Dispropotionate stratified random sampling adalah pengambilan sampel dari anggota populasi secara acak dan berstrata, tetapi sebagian ada yang kurang proporsional pembagiannya dengan anggota populasi yang heterogen. Sehingga anggota populasi dalam penelitian ini adalah pegawai Kelurahan Ciakar Kecamatan Cibeureum Kota Tasikmalaya. Adapun jumlah anggota populasi yang kemudian dijadikan sampel atau responden dengan menggunakan teknik sensus adalah sebanyak 9 orang.

Teknik pengolahan data dalam penelitian ini terdiri dari: (a) verifikasi data; (b) klasifikasi dan pengkodean; (c) entri data; (d) analisis statistik dan (e) membuat tampilan. Adapun langkah-langkah verifikasi data, sebagai berikut: (1) Mengevaluasi tenaga lapangan; (2) Memeriksa kelengkapan dan kejelasan data yang terkumpul; dan (3) Melihat kesatuan ukuran (Indrawan \& Yaniawati, 2016). Untuk mengetahui kondisi kinerja pegawai Kelurahan Ciakar Kecamatan Cibeureum Kota Tasikmalaya, peneliti melakukan pengukuran dengan menggunakan angket dan berisikan lima alternatif jawaban untuk setiap pernyataan. Hal tersebut sejalan dengan pendapat (Riduwan, 2011) yang menyatakan, bahwa "Skala Likert digunakan untuk mengukur sikap, pendapat dan persepsi seseorang atau kelompok tentang kejadian atau gejala sosial." Dengan demikian nilai terendah diberi skor 1 (satu) dan nilai tertinggi diberi skor 5 (lima).

\section{Hasil dan Pembahasan}

\section{A. Hasil Penelitian}

\section{Uji Validitas}

\section{a. Uji Validitas Kepemimpinan Lurah}

Sebelum penelitian dilakukan terlebih dahulu telah dilakukan uji validitas dan reliabilitas instrumen penelitian. Menurut (Arikunto, 2010) mengemukakan, "Validitas sebuah tes dapat diketahui dari hasil pemikiran dan dari hasil pengalaman". Hal tersebut sejalan dengan pendapat pada aturan Masrun (1979:13) yang menyatakan, bahwa "Untuk menguji validitas jika koefisien korelasi hasil hitung lebih dari atau sama dengan $0,3(r \geq 0,3)$ maka soal dikatakan valid." Dan untuk menguji reabilitas instrument dengan uji alpha Cronbach yang dianalisis dengan program statistik SPSS Versi 17.0 dan dikonsultasikan pada kriteria penafsiran korelasi dengan kategori indeks korelasi hasilnya ditunjukan seperti pada tabel dibawah, sebagai berikut: 
Tabel 2

Analisis Uji Validitas Instrumen tentang

Kepemimpinan Lurah (X)

No Koefisien Keterangan

Butir Instrumen Korelasi

\begin{tabular}{lcl}
\hline 1. & -.054 & Tidak Valid \\
\hline 2. & .837 & Valid \\
\hline 3. & .402 & Valid \\
\hline 4. & -.324 & Tidak Valid \\
\hline 5. & .709 & Valid \\
\hline 6. & .366 & Valid \\
\hline 7. & .939 & Valid \\
\hline 8. & .775 & Valid \\
\hline 9. & .748 & Valid \\
\hline 10. & .467 & Valid \\
\hline 11. & .793 & Valid \\
\hline 12. & .345 & Valid \\
\hline 13. & .950 & Valid \\
\hline 14. & -.399 & Tidak Valid \\
\hline
\end{tabular}

Sumber: SPSS Statistics Versi 17.0

Tabel di atas menunjukan bahwa instrument tentang kepemimpinan Lurah sejumlah 14 butir soal, item yang dinyatakan valid yaitu $>0,3$. Dari 14 item pertanyaan 3 (tiga) soal yang dinyatakan tidak valid yaitu nomor 1 , 4, dan 14. Sehingga instrument sebanyak 11 soal dapat digunakan sebagai alat untuk mengumpulkan data tentang kepemimpinan Lurah.

\section{b. Uji Validitas Kinerja Pegawai}

Uji Validitas digunakan untuk mengukur sah (valid) tidaknya suatu kuesioner, di mana item-itemnya tingkat validitas variabel kinerja pegawai (Y) dapat dilihat dalam tabel yang tersaji berikut ini :

Tabel 3

Analisis Uji Validitas Instrumen tentang Kinerja Pegawai (Y)

\begin{tabular}{lcl}
\hline $\begin{array}{l}\text { No } \\
\text { Butir Instrumen }\end{array}$ & $\begin{array}{l}\text { Koefisien } \\
\text { Korelasi }\end{array}$ & Keterangan \\
\hline 15. & .658 & Valid \\
\hline 16. & .335 & Valid \\
\hline 17. & .625 & Valid \\
\hline 18. & .550 & Valid \\
\hline 19. & .650 & Valid \\
\hline 20. & .578 & Valid \\
\hline 21. & .610 & Valid \\
\hline 22. & .660 & Valid \\
\hline 23. & .654 & Valid \\
\hline
\end{tabular}

Sumber: SPSS Statistics Versi 17.0 
Tabel di atas menunjukan bahwa instrument tentang manajemen sarana prasarana sejumlah 9 (sembilan) butir soal, item yang dinyatakan valid yaitu $>0,3$. Dari 9 (sembilan) item pertanyaan seluruhnya dinyatakan valid sehingga instrument sebanyak 9 soal dapat digunakan sebagai alat untuk mengumpulkan data tentang efektivitas kinerja pegawai.

\section{c. Karakteristik Responden}

Berdasarkan hasil kuesioner yang telah terkumpul dapat diperoleh karakteristik responden adalah pegawai di Kelurahan Ciakar Kecamatan Cibeureum Kota Tasikmalaya seperti tampak pada tabel dibawah ini:

Tabel 4

Profil Responden Berdasarkan Jenis Kelamin

\begin{tabular}{clcc}
\hline No. & Jenis Kelamin & F & \% \\
\hline 1. & Laki-laki & 6 & 60 \\
\hline 2. & Perempuan & 3 & 40 \\
\hline & Jumlah & 9 & 100 \\
\hline
\end{tabular}

Dari tabel di atas dapat dilihat bahwa jenis kelamin responden yang paling banyak dominan adalah laki-laki sebanyak 60\%, sedangkan jenis kelamin perempuan sebanyak $40 \%$. Jenis kelamin yang paling dominan yaitu laki-laki tidak terlalu mempengaruhi dalam pencapaian kinerja. Karena pada dasarnya baik laki-laki maupun perempuan mampu bekerja pada jabatan sesuai kualifikasinya.

Setelah mengetahui keadaan responden berdasarkan jenis kelamin, selanjutnya karakteristik berdasarkan tingkat pendidikan, sebagai berikut:

Tabel 5

Profil Responden Berdasarkan Tingkat Pendidikan

\begin{tabular}{llcc}
\hline No. & \multicolumn{1}{l}{ Pendidikan } & F & \% \\
\hline 1. & SMA/SMK/Sederajat & 5 & 55.6 \\
\hline 2. & Diploma /Sederajat & - & - \\
\hline 3. & Sarjana & 3 & 33.3 \\
\hline 4. & Pascasarjana & 1 & 11.1 \\
\hline Jumlah & 9 & 100
\end{tabular}

Berdasarkan profil responden berdasarkan tingkat pendidikan di Kelurahan Ciakar Kecamatan Cibeureum Kota Tasikmalaya yang dijadikan responden dalam peneliti ini, SLTA sebesar 55.6\%, Dilpoma tidak ada, Sarjana sebesar 33.3\% dan Pascasarjana sebesar $11.1 \%$.

Tabel 6 Profil Responden Berdasarkan Usia

\begin{tabular}{cccc}
\hline No. & Usia & F & \% \\
\hline 1. & $20-30$ tahun & 2 & 22.2 \\
\hline 2. & $31-40$ tahun & 3 & 33.3 \\
\hline 3. & 41 tahun ke atas & 4 & 44.4 \\
\hline & Jumlah & 9 & 100 \\
\hline
\end{tabular}


Berdasarkan tabel di atas bahwa profil responden berdasarkan usia di Kelurahan Ciakar Kecamatan Cibeureum yang dijadikan responden dalam peneliti ini, usia 20 - 30 tahun sebesar $22.2 \%$, 31 - 40 tahun sebesar $33.3 \%$ dan 41 tahun ke atas sebesar $44.4 \%$.

\section{d. Hasil Analisis tentang Variabel Kepemimpinan}

Untuk lebih jelasnya mengenai variabel kepemimpinan Lurah di Kelurahan Ciakar Kecamatan Cibeureum Kota Tasikmalaya, melalui penyebaran kuisioner yang terdiri dari daftar pernyataan-pernyataan yang berhubungan dengan variabel yang diteliti.

Untuk mengetahui tanggapan responden terhadap pernyataan kepemimpinan Lurah di Kelurahan Ciakar Kecamatan Cibeureum Kota Tasikmalaya, maka diperlukan data yang akan diperoleh responden dari penyebaran kuisioner terhadap 9 responden. Adapun kuisioner tersebut berisi pernyataan-pernyataan yang berhubungan dengan kepemimpinan. Dari jawaban responden, disusun kriteria penilaian. Menurut Sugiyono (2003:214) klasifikasi setiap indikator variabel $\mathrm{X}$ kepemimpinan Lurah dapat dihitung dengan langkah-langkah, sebagai berikut:

Nilai tertinggi setiap indikator kepemimpinan : $9 \times 5=45$

Nilai terendah setiap indikator kepemimpinan : 9 × $1=9$

$$
\begin{aligned}
\mathrm{N} & =\frac{\text { Nilai tertinggi-nilai terendah }}{\text { Z Kriteria pernyataan }} \\
& =\frac{45-9}{5} \\
& =7,2
\end{aligned}
$$

Adapun untuk klasifikasi kriteria penilaian untuk setiap indikator adalah sebagai berikut:

Tabel 7

Klasifikasi penilaian

\begin{tabular}{cc}
\hline Interval & Tingkat Pengaruh \\
\hline $9-16,2$ & Tidak Baik \\
\hline $16,3-23,4$ & Kurang Baik \\
\hline $23,5-30,6$ & Cukup Baik \\
\hline $30,7-37,8$ & Baik \\
\hline $37,9-45$ & Sangat Baik \\
\hline
\end{tabular}

Berdasarkan data-data yang dikumpulkan melalui kuisioner yang disebarkan kepada 9 responden diperoleh hasil mengenai kepemimpinan Lurah di Kelurahan Ciakar Kecamatan Cibeureum Kota Tasikmalaya. Secara lengkap hasil analisa tanggapan responden mengenai kepemimpinan Lurah, sebagai berikut: 
Tabel 8

Tanggapan Responden terhadap Kewenangan Lurah

\begin{tabular}{lcccc}
\hline $\begin{array}{l}\text { Tanggapan } \\
\text { Responden }\end{array}$ & Skor & Frekuensi & $\begin{array}{c}\text { Jumlah } \\
\text { Skor }\end{array}$ & Persentase \\
\hline Selalu & 5 & 5 & 25 & 55.6 \\
\hline Sering & 4 & 4 & 16 & 44.4 \\
\hline Kadang-kadang & 3 & - & - & - \\
\hline Hampir Tidak Pernah & 2 & - & - & - \\
\hline Tidak Pernah & 1 & - & - & - \\
\hline \multicolumn{1}{c}{ Jumlah } & & 9 & 41 & 100 \\
\hline
\end{tabular}

Tabel di atas menunjukan bahwa tanggapan reponden tentang kesesuaian penggunaan kewenangan Lurah, responden yang menyatakan selalu 55,6\%, dan sering 44,4\%. Hal tersebut memberikan gambaran bahwa jumlah skor keseluruhan sebesar 41 atau kriteria sangat baik. Artinya Lurah sudah sangat baik dalam menjalankan kewenangannya.

Tabel 9

Tanggapan Responden terhadap Pengaruh Lurah

\begin{tabular}{|c|c|c|c|c|}
\hline $\begin{array}{l}\text { Tanggapan } \\
\text { Responden }\end{array}$ & Skor & Frekuensi & $\begin{array}{c}\text { Jumlah } \\
\text { Skor }\end{array}$ & Persentase \\
\hline Selalu & 5 & 4 & 20 & 44.4 \\
\hline Sering & 4 & 3 & 12 & 33.3 \\
\hline Kadang-kadang & 3 & 2 & 6 & 22.3 \\
\hline Hampir Tidak Pernah & 2 & - & - & - \\
\hline Tidak Pernah & 1 & - & - & - \\
\hline Jumlah & & 9 & 38 & 100 \\
\hline
\end{tabular}

pengaruh Lurah, responden yang menyatakan selalu 44,4\%, menyatakan sering 33,3\%, dan kadang-kadang 22,3\%. Hal tersebut memberikan gambaran bahwa jumlah skor keseluruhan sebesar 38 atau kriteria sangat baik. Artinya kepemimpinan Lurah sangat berpengaruh di lingkungan kerjanya.

\section{Tabel 10}

Tanggapan Responden terhadap Taktik Mempengaruhi Orang Lain

\begin{tabular}{lcccc}
\hline $\begin{array}{l}\text { Tanggapan } \\
\text { Responden }\end{array}$ & Skor & Frekuensi & $\begin{array}{c}\text { Jumlah } \\
\text { Skor }\end{array}$ & Persentase \\
\hline Selalu & 5 & 2 & 10 & 22.3 \\
\hline Sering & 4 & 4 & 16 & 44.4 \\
\hline Kadang-kadang & 3 & 3 & 9 & 33.3 \\
\hline Hampir Tidak Pernah & 2 & - & - & - \\
\hline Tidak Pernah & 1 & - & - & - \\
\hline \multicolumn{1}{c}{ Jumlah } & & 9 & 35 & 100 \\
\hline
\end{tabular}

Tabel di atas menunjukan bahwa tanggapan reponden tentang taktik Lurah dalam mempengaruhi orang lain, responden yang menyatakan selalu $44,4 \%$, menyatakan sering 33,3\%, dan kadang-kadang 22,3\%. Hal tersebut memberikan gambaran bahwa jumlah skor keseluruhan sebesar 35 atau 
kriteria baik. Artinya Lurah sudah mempunyai taktik yang baik dalam mempengaruhi bawahannya.

Tabel 11

Tanggapan Responden terhadap Kharisma Lurah

\begin{tabular}{lcccc}
\hline $\begin{array}{l}\text { Tanggapan } \\
\text { Responden }\end{array}$ & Skor & Frekuensi & $\begin{array}{c}\text { Jumlah } \\
\text { Skor }\end{array}$ & Persentase \\
\hline Selalu & 5 & 7 & 35 & 77.8 \\
\hline Sering & 4 & 2 & 8 & 22.2 \\
\hline Kadang-kadang & 3 & - & - & - \\
\hline Hampir Tidak Pernah & 2 & - & - & - \\
\hline Tidak Pernah & 1 & - & - & - \\
\hline \multicolumn{1}{c}{ Jumlah } & & 9 & 43 & 100 \\
\hline
\end{tabular}

Tabel di atas menunjukan bahwa tanggapan reponden tentang kharisma Lurah, responden yang menyatakan selalu 77,8\% dan sering 22,2\%. Hal tersebut memberikan gambaran bahwa jumlah skor keseluruhan sebesar 43 atau kriteria sangat baik. Artinya Lurah mempunyai kharisma yang sangat baik.

Tabel 12

Tanggapan Responden terhadap Hard Competence

\begin{tabular}{lcccc}
\hline $\begin{array}{l}\text { Tanggapan } \\
\text { Responden }\end{array}$ & Skor & Frekuensi & $\begin{array}{c}\text { Jumlah } \\
\text { Skor }\end{array}$ & Persentase \\
\hline Selalu & 5 & 4 & 20 & 44.4 \\
\hline Sering & 4 & 4 & 16 & 44.4 \\
\hline Kadang-kadang & 3 & 1 & 3 & 11.2 \\
\hline Hampir Tidak Pernah & 2 & - & - & - \\
\hline Tidak Pernah & 1 & - & - & - \\
\hline \multicolumn{1}{c}{ Jumlah } & & 9 & 39 & 100 \\
\hline
\end{tabular}

Tabel di atas menunjukan bahwa tanggapan reponden tentang hard competence Lurah, responden yang menyatakan selalu $44,4 \%$, sering $44,4 \%$, dan kadang-kadang 11,2\%. Hal tersebut memberikan gambaran bahwa jumlah skor keseluruhan sebesar 39 atau kriteria sangat baik. Artinya Lurah mempunyai hard competence yang sangat baik.

Tabel 13

Tanggapan Responden terhadap Soft Competence

\begin{tabular}{lcccc}
\hline $\begin{array}{l}\text { Tanggapan } \\
\text { Responden }\end{array}$ & Skor & Frekuensi & $\begin{array}{c}\text { Jumlah } \\
\text { Skor }\end{array}$ & Persentase \\
\hline Selalu & 5 & 3 & 15 & 33.4 \\
\hline Sering & 4 & 3 & 12 & 33.3 \\
\hline Kadang-kadang & 3 & 3 & 9 & 33.3 \\
\hline Hampir Tidak Pernah & 2 & - & - & - \\
\hline Tidak Pernah & 1 & - & - & - \\
\hline \multicolumn{1}{c}{ Jumlah } & & 9 & 36 & 100 \\
\hline
\end{tabular}

Tabel di atas menunjukan bahwa tanggapan reponden tentang soft competence Lurah, responden yang menyatakan selalu 33,4\%, sering 33,3\%, dan kadang-kadang 33,3\%. Hal tersebut memberikan gambaran bahwa 
jumlah skor keseluruhan sebesar 36 atau kriteria baik. Artinya Lurah mempunyai soft competence yang baik.

Tabel 14

Tanggapan Responden terhadap Kompetensi Minimal

\begin{tabular}{|c|c|c|c|c|}
\hline $\begin{array}{l}\text { Tanggapan } \\
\text { Responden }\end{array}$ & Skor & Frekuensi & $\begin{array}{l}\text { Jumlah } \\
\text { Skor }\end{array}$ & Persentase \\
\hline Selalu & 5 & 2 & 10 & 22.2 \\
\hline Sering & 4 & 5 & 20 & 55.6 \\
\hline Kadang-kadang & 3 & - & - & - \\
\hline Hampir Tidak Pernah & 2 & - & - & - \\
\hline Tidak Pernah & 1 & 2 & 2 & 22.2 \\
\hline Jumlah & & 9 & 33 & 100 \\
\hline
\end{tabular}

kompetensi minimal Lurah, responden yang menyatakan selalu $22,2 \%$, sering $55,6 \%$, dan tidak pernah $22,2 \%$. Hal tersebut memberikan gambaran bahwa jumlah skor keseluruhan sebesar 33 atau kriteria baik. Artinya Lurah mempunyai kompetensi minimal yang baik.

Tabel 15

Tanggapan Responden terhadap Kompetensi Maksimal

\begin{tabular}{lcccc}
\hline $\begin{array}{l}\text { Tanggapan } \\
\text { Responden }\end{array}$ & Skor & Frekuensi & $\begin{array}{c}\text { Jumlah } \\
\text { Skor }\end{array}$ & Persentase \\
\hline Selalu & 5 & 5 & 25 & 55.6 \\
\hline Sering & 4 & 3 & 12 & 33.3 \\
\hline Kadang-kadang & 3 & 1 & 3 & 11.1 \\
\hline Hampir Tidak Pernah & 2 & - & - & - \\
\hline Tidak Pernah & 1 & - & - & - \\
\hline \multicolumn{1}{c}{ Jumlah } & & 9 & 40 & 100 \\
\hline
\end{tabular}

Tabel di atas menunjukan bahwa tanggapan reponden tentang kompetensi maksimal Lurah, responden yang menyatakan selalu 55,6\%, sering 33,3\%, dan kadang-kadang 11,1\%. Hal tersebut memberikan gambaran bahwa jumlah skor keseluruhan sebesar 40 atau kriteria baik. Artinya Lurah mempunyai kompetensi maksimal yang baik.

Tabel 16

Tanggapan Responden terhadap Kejujuran

\begin{tabular}{|c|c|c|c|c|}
\hline $\begin{array}{l}\text { Tanggapan } \\
\text { Responden }\end{array}$ & Skor & Frekuensi & $\begin{array}{l}\text { Jumlah } \\
\text { Skor }\end{array}$ & Persentase \\
\hline Selalu & 5 & 5 & 25 & 55.6 \\
\hline Sering & 4 & 3 & 12 & 33.3 \\
\hline Kadang-kadang & 3 & 1 & 3 & 11.1 \\
\hline Hampir Tidak Pernah & 2 & - & - & - \\
\hline Tidak Pernah & 1 & - & - & - \\
\hline Jumlah & & 9 & 40 & 100 \\
\hline
\end{tabular}

kejujuran Lurah, responden yang menyatakan selalu 55,6\%, sering 33,3\%, 
dan kadang-kadang 11,1\%. Hal tersebut memberikan gambaran bahwa jumlah skor keseluruhan sebesar 40 atau kriteria baik. Artinya Lurah mempunyai tingkat kejujuran yang baik.

Tabel 17

Tanggapan Responden terhadap Tanggung Jawab

\begin{tabular}{lcccc}
\hline $\begin{array}{l}\text { Tanggapan } \\
\text { Responden }\end{array}$ & Skor & Frekuensi & $\begin{array}{c}\text { Jumlah } \\
\text { Skor }\end{array}$ & Persentase \\
\hline Selalu & 5 & 4 & 20 & 44.4 \\
\hline Sering & 4 & 5 & 20 & 55.6 \\
\hline Kadang-kadang & 3 & - & - & - \\
\hline Hampir Tidak Pernah & 2 & - & - & - \\
\hline Tidak Pernah & 1 & - & - & - \\
\hline \multicolumn{1}{c}{ Jumlah } & & 9 & 40 & 100 \\
\hline
\end{tabular}

Tabel di atas menunjukan bahwa tanggapan reponden tentang tanggung jawab Lurah, responden yang menyatakan selalu $44,4 \%$ dan sering $55,6 \%$. Hal tersebut memberikan gambaran bahwa jumlah skor keseluruhan sebesar 40 atau kriteria baik. Artinya Lurah mempunyai tanggung jawab yang baik.

Tabel 18

Tanggapan Responden terhadap Motivasi

\begin{tabular}{lcccc}
\hline $\begin{array}{l}\text { Tanggapan } \\
\text { Responden }\end{array}$ & Skor & Frekuensi & $\begin{array}{c}\text { Jumlah } \\
\text { Skor }\end{array}$ & Persentase \\
\hline Selalu & 5 & 4 & 20 & 44.4 \\
\hline Sering & 4 & 4 & 16 & 44.4 \\
\hline Kadang-kadang & 3 & 1 & 3 & 11.2 \\
\hline Hampir Tidak Pernah & 2 & - & - & - \\
\hline Tidak Pernah & 1 & - & - & - \\
\hline \multicolumn{1}{c}{ Jumlah } & & 9 & 39 & 100 \\
\hline
\end{tabular}

Tabel di atas menunjukan bahwa tanggapan reponden tentang motivasi Lurah, responden yang menyatakan selalu 44,4\%, sering 44,4\%, dan kadang-kadang $11,2 \%$. Hal tersebut memberikan gambaran bahwa jumlah skor keseluruhan sebesar 39 atau sangat baik. Artinya Lurah mempunyai motivasi yang tinggi.

Tabel 19

Tanggapan Responden terhadap Ketekunan

\begin{tabular}{lcccc}
\hline Tanggapan Responden & Skor & Frekuensi & Jumlah Skor & Persentase \\
\hline Selalu & 5 & 4 & 20 & 44.4 \\
\hline Sering & 4 & 4 & 16 & 44.4 \\
\hline Kadang-kadang & 3 & 1 & 3 & 11.2 \\
\hline Hampir Tidak Pernah & 2 & - & - & - \\
\hline Tidak Pernah & 1 & - & - & - \\
\hline \multicolumn{1}{c}{ Jumlah } & & 9 & 40 & 100 \\
\hline
\end{tabular}


Tabel di atas menunjukan bahwa tanggapan reponden tentang ketekunan Lurah, responden yang menyatakan selalu 44,4\%, sering 44,4\%, dan kadang-kadang 11,2\%. Hal tersebut memberikan gambaran bahwa jumlah skor keseluruhan sebesar 40 atau sangat baik. Artinya Lurah mempunyai ketekunan yang tinggi.

Tabel 20

Tanggapan Responden terhadap Keberanian Internal

\begin{tabular}{|c|c|c|c|c|}
\hline $\begin{array}{l}\text { Tanggapan } \\
\text { Responden }\end{array}$ & Skor & Frekuensi & $\begin{array}{c}\text { Jumlah } \\
\text { Skor }\end{array}$ & Persentase \\
\hline Selalu & 5 & 4 & 20 & 44.4 \\
\hline Sering & 4 & 3 & 12 & 33.3 \\
\hline Kadang-kadang & 3 & - & - & - \\
\hline Hampir Tidak Pernah & 2 & 2 & 4 & 22.3 \\
\hline Tidak Pernah & 1 & - & - & - \\
\hline Jumlah & & 9 & 36 & 100 \\
\hline
\end{tabular}

keberanian internal Lurah, responden yang menyatakan selalu 44,4\%, sering $33,3 \%$, dan hampir tidak pernah 22,3\%. Hal tersebut memberikan gambaran bahwa jumlah skor keseluruhan sebesar 36 atau baik. Artinya Lurah mempunyai keberanian internal yang tinggi.

Tabel 21

Tanggapan Responden terhadap Keberanian Eksternal

\begin{tabular}{lcccc}
\hline $\begin{array}{l}\text { Tanggapan } \\
\text { Responden }\end{array}$ & Skor & Frekuensi & $\begin{array}{c}\text { Jumlah } \\
\text { Skor }\end{array}$ & Persentase \\
\hline Selalu & 5 & 1 & 5 & 11.1 \\
\hline Sering & 4 & 2 & 8 & 22.2 \\
\hline Kadang-kadang & 3 & - & - & - \\
\hline Hampir Tidak Pernah & 2 & - & - & - \\
\hline Tidak Pernah & 1 & 6 & 6 & 66.7 \\
\hline \multicolumn{1}{c}{ Jumlah } & & 9 & 19 & 100 \\
\hline
\end{tabular}

Tabel di atas menunjukan bahwa tanggapan reponden tentang keberanian eksternal Lurah, responden yang menyatakan selalu $11,1 \%$, sering $22,2 \%$, dan tidak pernah $66,7 \%$. Hal tersebut memberikan gambaran bahwa jumlah skor keseluruhan sebesar 19 atau kurang baik. Artinya Lurah mempunyai keberanian eksternal yang kurang baik.

\section{e. Hasil Analisis tentang Variabel Kinerja Pegawai}

Untuk lebih jelasnya mengenai variabel kinerja pegawai di Kelurahan Ciakar Kecamatan Cibeureum Kota Tasikmalaya, melalui penyebaran kuisioner yang terdiri dari daftar pernyataan-pernyataan yang berhubungan dengan variabel yang diteliti.

Untuk mengetahui tanggapan responden terhadap pernyataan kinerja pegawai di Kelurahan Ciakar Kecamatan Cibeureum Kota Tasikmalaya, maka diperlukan data yang akan diperoleh responden dari penyebaran 
kuisioner terhadap 9 responden. Adapun kuisioner tersebut berisi pernyataanpernyataan yang berhubungan dengan kinerja pegawai. Dari jawaban responden, disusun kriteria penilaian. Menurut Sugiyono (2003:214) klasifikasi setiap indikator variabel (Y) kinerja pegawai dapat dihitung dengan langkah-langkah, sebagai berikut:

Nilai tertinggi setiap indikator kinerja: 9 x $5=45$

Nilai terendah setiap indikator kinerja : $9 \times 1=9$

$$
\begin{aligned}
\mathrm{N} & =\frac{\text { Nilai tertinggi-nilai terendah }}{\mathrm{Z} \text { Kriteria pernyataan }} \\
& =\frac{45-9}{5} \\
& =7,2
\end{aligned}
$$

Tabel 22

Tanggapan Responden terhadap Kesempurnaan Pekerjaan

\begin{tabular}{lcccc}
\hline $\begin{array}{l}\text { Tanggapan } \\
\text { Responden }\end{array}$ & Skor & Frekuensi & $\begin{array}{c}\text { Jumlah } \\
\text { Skor }\end{array}$ & Persentase \\
\hline Selalu & 5 & 3 & 15 & 33.3 \\
\hline Sering & 4 & 1 & 4 & 11.1 \\
\hline Kadang-kadang & 3 & 4 & 12 & 44.5 \\
\hline Hampir Tidak Pernah & 2 & 1 & 2 & 11.1 \\
\hline Tidak Pernah & 1 & - & - & - \\
\hline \multicolumn{1}{c}{ Jumlah } & & 9 & 40 & 100 \\
\hline
\end{tabular}

Tabel di atas menunjukan bahwa tanggapan reponden tentang kesempurnaan pekerjaan pegawai, responden yang menyatakan selalu 33,3\%, sering $11,1 \%$, kadang-kadang $44,5 \%$, dan hampir tidak pernah $11,1 \%$. Hal tersebut memberikan gambaran bahwa jumlah skor keseluruhan sebesar 40 atau sangat baik. Artinya pegawai mempunyai tingkat kesempurnaan dalam menyelesaikan pekerjaan sangat baik.

Tabel 23

Tanggapan Responden terhadap Keterampilan Kerja

\begin{tabular}{lcccc}
\hline $\begin{array}{l}\text { Tanggapan } \\
\text { Responden }\end{array}$ & Skor & Frekuensi & $\begin{array}{c}\text { Jumlah } \\
\text { Skor }\end{array}$ & Persentase \\
\hline Selalu & 5 & 1 & 5 & 11.1 \\
\hline Sering & 4 & 2 & 8 & 22.2 \\
\hline Kadang-kadang & 3 & 4 & 12 & 44.5 \\
\hline Hampir Tidak Pernah & 2 & 2 & 4 & 22.2 \\
\hline Tidak Pernah & 1 & - & - & - \\
\hline \multicolumn{1}{c}{ Jumlah } & & 9 & 29 & 100 \\
\hline \multicolumn{2}{c}{ Tabel di atas } & menunjukan & bahwa & tanggapan \\
\hline
\end{tabular}

keterampilan kerja pegawai, responden yang menyatakan selalu $11,1 \%$, sering $22,2 \%$, kadang-kadang 44,5\%, dan hampir tidak pernah 22,2\%. Hal tersebut memberikan gambaran bahwa jumlah skor keseluruhan sebesar 29 atau cukup baik. Artinya pegawai mempunyai keterampilan kerja cukup baik.

\section{Tabel 24}


Tanggapan Responden terhadap Jumlah Pekerjaan yang Diselesaikan

\begin{tabular}{lcccc}
\hline $\begin{array}{l}\text { Tanggapan } \\
\text { Responden }\end{array}$ & Skor & Frekuensi & $\begin{array}{c}\text { Jumlah } \\
\text { Skor }\end{array}$ & Persentase \\
\hline Selalu & 5 & 2 & 10 & 22.3 \\
\hline Sering & 4 & 3 & 12 & 33.3 \\
\hline Kadang-kadang & 3 & 3 & 9 & 33.3 \\
\hline Hampir Tidak Pernah & 2 & 1 & 2 & 11.1 \\
\hline Tidak Pernah & 1 & - & - & - \\
\hline \multicolumn{1}{c}{ Jumlah } & & 9 & 33 & 100 \\
\hline
\end{tabular}

Tabel di atas menunjukan bahwa tanggapan reponden tentang jumlah pekerjaan yang diselesaikan pegawai, responden yang menyatakan selalu $22,3 \%$, sering 33,3\%, kadang-kadang 33,3\%., dan hampir tidak pernah $11,1 \%$. Hal tersebut memberikan gambaran bahwa jumlah skor keseluruhan sebesar 33 atau baik. Artinya pegawai dapat menyelesaikan setiap pekerjaan dengan baik.

Tabel 25

Tanggapan Responden terhadap Kedisiplinan Kerja

\begin{tabular}{|c|c|c|c|c|}
\hline $\begin{array}{l}\text { Tanggapan } \\
\text { Responden }\end{array}$ & Skor & Frekuensi & $\begin{array}{c}\text { Jumlah } \\
\text { Skor }\end{array}$ & Persentase \\
\hline Selalu & 5 & 4 & 20 & 44.5 \\
\hline Sering & 4 & 1 & 4 & 11.1 \\
\hline Kadang-kadang & 3 & 3 & 9 & 33.3 \\
\hline Hampir Tidak Pernah & 2 & 1 & 2 & 11.1 \\
\hline Tidak Pernah & 1 & - & - & - \\
\hline Jumlah & & 9 & 35 & 100 \\
\hline
\end{tabular}

kedisiplinan kerja pegawai, responden yang menyatakan selalu 44,5\%, sering $11,1 \%$, kadang-kadang 33,3\%, dan hampir tidak pernah $11,1 \%$. Hal tersebut memberikan gambaran bahwa jumlah skor keseluruhan sebesar 35 atau baik. Artinya pegawai mempunyai kedisiplinan kerja yang baik.

Tabel 26

Tanggapan Responden terhadap Ketepatan Penyelesaian Pekerjaan

\begin{tabular}{lcccc}
\hline $\begin{array}{l}\text { Tanggapan } \\
\text { Responden }\end{array}$ & Skor & Frekuensi & $\begin{array}{c}\text { Jumlah } \\
\text { Skor }\end{array}$ & Persentase \\
\hline Selalu & 5 & 3 & 15 & 33.3 \\
\hline Sering & 4 & 2 & 8 & 22.2 \\
\hline Kadang-kadang & 3 & 3 & 9 & 33.3 \\
\hline Hampir Tidak Pernah & 2 & 1 & 2 & 11.2 \\
\hline Tidak Pernah & 1 & - & - & - \\
\hline \multicolumn{1}{c}{ Jumlah } & & 9 & 35 & 100
\end{tabular}

Tabel di atas menunjukan bahwa tanggapan reponden tentang ketepatan penyelesaian pekerjaan oleh pegawai, responden yang menyatakan selalu 33,3\%, sering 22,2\%, kadang-kadang 33,3\%, dan hampir tidak pernah $11,2 \%$. Hal tersebut memberikan gambaran bahwa jumlah skor keseluruhan 
sebesar 35 atau baik. Artinya pegawai mempunyai tingkat ketepatan penyelesaian pekerjaan dengan baik.

Tabel 27

Tanggapan Responden terhadap Penggunaan Sumber Daya

\begin{tabular}{lcccc}
\hline $\begin{array}{l}\text { Tanggapan } \\
\text { Responden }\end{array}$ & Skor & Frekuensi & $\begin{array}{c}\text { Jumlah } \\
\text { Skor }\end{array}$ & Persentase \\
\hline Selalu & 5 & 6 & 30 & 66.7 \\
\hline Sering & 4 & 2 & 8 & 22.2 \\
\hline Kadang-kadang & 3 & - & - & - \\
\hline Hampir Tidak Pernah & 2 & 1 & 2 & 11.1 \\
\hline Tidak Pernah & 1 & - & - & - \\
\hline \multicolumn{1}{c}{ Jumlah } & & 9 & 40 & 100 \\
\hline
\end{tabular}

Tabel di atas menunjukan bahwa tanggapan reponden tentang penggunaan sumber daya oleh pegawai, responden yang menyatakan selalu $66,7 \%$, sering 22,2\%, dan hampir tidak pernah $11,1 \%$. Hal tersebut memberikan gambaran bahwa jumlah skor keseluruhan sebesar 40 atau sangat baik. Artinya pegawai selalu menggunakan sumber daya dengan sangat baik.

Tabel 28

Tanggapan Responden terhadap Berorientasi pada Hasil

\begin{tabular}{lcccc}
\hline $\begin{array}{l}\text { Tanggapan } \\
\text { Responden }\end{array}$ & Skor & Frekuensi & $\begin{array}{c}\text { Jumlah } \\
\text { Skor }\end{array}$ & Persentase \\
\hline Selalu & 5 & 3 & 15 & 33.3 \\
\hline Sering & 4 & 2 & 8 & 33.2 \\
\hline Kadang-kadang & 3 & 3 & 9 & 33.3 \\
\hline Hampir Tidak Pernah & 2 & 1 & 2 & 11.2 \\
\hline Tidak Pernah & 1 & - & - & - \\
\hline \multicolumn{1}{c}{ Jumlah } & & 9 & 34 & 100 \\
\hline
\end{tabular}

Tabel di atas menunjukan bahwa tanggapan reponden tentang pegawai yang berorientasi pada hasil, responden yang menyatakan selalu 33,2\%, sering 33,2\%, dan hampir tidak pernah $11,2 \%$. Hal tersebut memberikan gambaran bahwa jumlah skor keseluruhan sebesar 34 atau baik. Artinya pegawai selalu berorientasi pada hasil dengan baik.

Tabel 29

Tanggapan Responden terhadap Kemitraan Kerja

\begin{tabular}{|c|c|c|c|c|}
\hline $\begin{array}{l}\text { Tanggapan } \\
\text { Responden }\end{array}$ & Skor & Frekuensi & $\begin{array}{c}\text { Jumlah } \\
\text { Skor }\end{array}$ & Persentase \\
\hline Selalu & 5 & 2 & 10 & 22.2 \\
\hline Sering & 4 & 2 & 8 & 22.2 \\
\hline Kadang-kadang & 3 & 2 & 6 & 22.2 \\
\hline Hampir Tidak Pernah & 2 & 3 & 6 & 33.4 \\
\hline Tidak Pernah & 1 & - & - & - \\
\hline Jumlah & & 9 & 30 & 100 \\
\hline
\end{tabular}

kemitraan kerja pegawai, responden yang menyatakan selalu 22,2\%, sering $22,2 \%$, kadang-kadang 22,2\% dan hampir tidak pernah 33,4\%. Hal tersebut 
memberikan gambaran bahwa jumlah skor keseluruhan sebesar 30 atau cukup baik. Artinya pegawai selalu bermitra cukup baik dengan pegawai yang lainnya.

Tabel 30

Tanggapan Responden terhadap Tanggung Jawab

\begin{tabular}{|c|c|c|c|c|}
\hline $\begin{array}{l}\text { Tanggapan } \\
\text { Responden }\end{array}$ & Skor & Frekuensi & $\begin{array}{c}\text { Jumlah } \\
\text { Skor }\end{array}$ & Persentase \\
\hline Selalu & 5 & 5 & 25 & 55.6 \\
\hline Sering & 4 & 2 & 8 & 22.2 \\
\hline Kadang-kadang & 3 & 2 & 6 & 22.2 \\
\hline Hampir Tidak Pernah & 2 & - & - & - \\
\hline Tidak Pernah & 1 & - & - & - \\
\hline Jumlah & & 9 & 39 & 100 \\
\hline
\end{tabular}

tanggung jawab pegawai, responden yang menyatakan selalu 55,6\%, sering $22,2 \%$, dan kadang-kadang 22,2\%. Hal tersebut memberikan gambaran bahwa jumlah skor keseluruhan sebesar 39 atau sangat baik. Artinya pegawai bertanggung jawab dengan sangat baik.

\section{f. Pengujian Hipotesis Penelitian}

Interpretasi hasil pengujian hipotesis melalui analisis korelasi bivariat untuk $(X)$ sebagai variabel bebas, yaitu kepemimpinan Lurah dan $(Y)$ sebagai variabel terikat, yakni kinerja pegawai, dilakukan pengolahan data dengan Program SPSS Statistics Versi 17.0.

Pengujian hipotesis dilakukan guna mengetahui apakah hipotesis yang diajukan dalam penelitian ini dapat diterima atau ditolak. Pengolahan data tersebut menggunakan program SPSS 17.0. Untuk mengetahui sejauhmana hubungan kedua variabel tersebut di atas, maka penulis menggunakan rumus koefisien korelasi yang hasilnya penulis sajikan dalam tabel sebagai berikut:

Tabel 31

Correlations Pengaruh Kepemimpinan Lurah terhadap Kinerja Pegawai Correlations

\begin{tabular}{llrr}
\hline & & Kepemimpinan & Kinerja \\
\hline Kepemimpinan & Pearson Correlation & 1 & .469 \\
& Sig. (2-tailed) & & .203 \\
& $\mathrm{~N}$ & 9 & 9 \\
\hline Kinerja & Pearson Correlation & .469 & 1 \\
& Sig. (2-tailed) & .203 & \\
& $\mathrm{~N}$ & 9 & 9 \\
\hline
\end{tabular}

Sumber: SPPS Statistics Versi 17.0

Tabel tersebut di atas menunjukkan matriks korelasi antara dua variabel. Korelasi antara kepemimpinan Lurah terhadap kinerja pegawai diperoleh angka 0.469 , hal ini berarti $46,9 \%$ data keduanya sangat 
berhubungan secara positif. Lebih jauh hasil tingkat korelasi dari data tersebut mempunyai tingkat hubungan yang cukup kuat, yakni berada diantara 0.40 0.599 .

\section{B. Pembahasan}

Berdasarkan hasil analisis hipotesis besarnya pengaruh kepemimpinan lurah terhadap efektivitas kinerja pegawai adalah berpengaruh cukup kuat. Pada dasarnya kepemimpinan tidak lepas dari seorang pemimpin yang efektif, membawa iklim kondusif di dalam organisasi tersebut. Sejalan dengan pendapat Peter, Drucker dalam (Agustinus, 2016) menyatakan, bahwa"Pemimpin efektif dapat menggugah pengikutnya melakukan sesuatu. Pemimpin itu nyata, mereka orangorang yang memberi teladan. Kepemimpinan itu tanggung jawab, bukan hak istimewa, gelar atau uang.

Efektivitas kinerja pegawai di Kelurahan Ciakar Kecamatan Cibeureum Kota Tasikmalaya, dipengaruhi oleh beberapa faktor intern dan ekstern dari kepemimpinan seorang Lurah dijelaskan, sebagai berikut:

\section{Faktor Internal}

a. Kekuasaan

Kekuasaan yang berasal dari individu ini sering disebut dengan pengaruh. Kekuasaan tersebut berasal dari expert power, referent power, information power, connection and relationship power, dan charismatic power.

b. Kompetensi

Seorang pemimpin tentunya harus mempunyai skill atau kemampuan keterampilan dan pengetahuan.

c. Kredibilitas

Kredibilitas merupakan sifat dapat dipercaya. Sehingga kredibilitas akan menimbulkan hubungan kerja yang efisien antara pemimpin dan yang dipimpin. Selain itu dapat meningkatkan keeratan hubungan dan meningkatkan produktivitas.

d. Kemauan dan semangat

Jika seorang pemimpin menjangkau orang lain dengan penuh semangat, maka dia juga akan disambut dengan penuh semangat. Kemauan dan semangat merupakan motivasi pribadi dalam menjalankan aktivitas dalam sebuah organisasi.

e. Keberanian

Keberanian internal merupakan keberanian seorang pemimpin untuk mendengar nurani pemimpin dan menjalankannya tanpa kompromi.

\section{Faktor Eksternal}

a. Kekuasaan yang Berasal dari Organisasi

Kekuasaan yang berasal dari organisasi merupakan kewenangan atau otoritas, yakni yang dipimpin mau mengikuti pemimpin karena 
Endri Herlambang

keharusan. Kekuasaan ini berasal dari penunjukan formal, reward power, dan coersive power.

b. Keberanian Eksternal

Suatu organisasi tidak selalu berjalan dengan baik tanpa hambatan. Terkadang banyak hambatan-hambatan dan tantangan-tantangan, dimana pemimpin harus mengambil suatu keputusan yang mengandung resiko. Sehingga ada kalanya pemimpin harus menghadapi orang-orang yang menentang terhadapnya.

\section{Kesimpulan}

Berdasarkan hasil penelitian dan pembahasan tentang pengaruh kepemimpinan Lurah terhadap efektivitas kinerja pegawai di Kelurahan Ciakar Kecamatan Cibeureum Kota Tasikmalaya, dapat di simpulkan sebagai berikut:

Kepemimpinan Lurah berpoengaruh positif dan signifikan terhadap efektivitas kinerja pegawai di Kelurahan Ciakar Kecamatan Cibeureum Kota Tasikmalaya. Artinya; semakin tinggi pengaruh kepemimpinan, maka kinerja pegawai akan meningkat. Kepemimpinan meliputi; kekuasaan, kompetensi, kredibilitasm, keberanian, kemauan dan semangat. 
Pengaruh Kepemimpinan Lurah Terhadap Efektivitas Kinerja Pegawai

\section{BIBLIOGRAFI}

Agustinus, Johanes Djohan. (2016). Lima Pilar Kepemimpinan Di Abad 21. Media Nusa Creative.

Arikunto, Suharsimi. (2010). Prosedur Penelitian Sebuah Pendekatan Praktek. Jakarta: Rineka Cipta.

Hasibuan, Malayu S. P. (2009). Manajemen sumber daya manusia, Cetakan ketujuh. Jakarta: PT. Bumi Aksara.

Heridiansyah, Jefri. (2014). Manajemen Konflik dalam Sebuah Organisasi. Jurnal STIE Semarang, 6(1), 28-41.

Indonesia, Ombudsman Republik. (2015). Laporan tahunan 2015. Jakarta: KKI.

Indrawan, Rully, \& Yaniawati, Poppy. (2016). Metodologi Penelitian Kuantitatif, Kualitatif dan Campuran. PT REFIKA Aditama. Bandung.

Mangkunegara, A. A., \& Prabu, Anwar. (2005). Evaluasi kerja SDM. Bandung: PT. Refika Aditama.

Riduwan, Sunarto. (2011). Pengantar Statistika untuk penelitian pendidikan, sosial, ekonomi, komunikasi dan bisnis. Cetakan Ke-4 Bandung: Alfabeta.

Taniredja, Tukiran, \& Mustafidah, Hidayati. (2011). Penelitian Kuantitatif (sebuah pengantar). Bandung: Alfabeta. 